\title{
5-Ene-rhodanine-3-carboxylic acids as potential antimicrobial and antiparasitic agents
}

\author{
A. P. Kryshchyshyn-Dylevych \\ Danylo Halytsky Lviv National Medical University \\ 69, Pekarska Str., Lviv, Ukraine, 79010 \\ kryshchyshyn.a@gmail.com
}

\begin{abstract}
Aim. Design, synthesis and study of antibacterial, antifungal and trypanocidal activity of a series of novel 2-thioxo-4-thiazolidinone-3-carboxylic acids with different arylidene substituents in C5 position. Methods. Organic wet synthesis, analytical and spectral methods, pharmacological screening, SAR analysis. Results. A series of 5-(aminomethylene)-4-oxo-2-thioxothiazolidin-3-ylcarboxylic acids and their analogs IIIa-IIIj were synthesized in the reactions of 5-(ethoxymethylene)-4-oxo-2-thioxothiazolidin-3-ylcarboxylic acids IIa,b or ethyl 5-(ethoxymethylene)-4-oxo-2-thioxothiazolidin-3-ylpropanoate IIc with various amines and ammonium hydrogen carbonate. Five of the synthesized compounds IIIb, IIIf and IIIh-j were tested towards a series of Gram (+) and Gram (-) bacteria and four yeasts strains at a dose of $1 \mathrm{mM}$. In general, the tested compounds are promising building scaffolds for the development of antifungal agents as all of them inhibited growth of clinical strain of Candida albicans. Moreover, pyridine containing 3-[5-(aminomethylene)-rhodanine-3-yl]carboxylates showed good trypanocidal activity and low cytotoxicity towards normal fibroblasts. Conclusions. A series of novel 3-[5-(aminomethylene)-4-oxo-2-thioxothiazolidin-3-yl]carboxylic acids derivatives were synthesized. Study of their antibacterial and antifungal action allowed identifying a hit-compound ethyl 3-[5-[(4-(fluoroanilino)methylene]-4-oxo-2-thioxothiazolidin-3-yl] propanoate IIIf, which is active against clinical strains of Staphylococcus lentus and Candida ssp. In general, most of the studied compounds showed good antifungal properties.
\end{abstract}

Ke y w or d s: 2-thioxo-4-thiazolidinone-3-carboxylic acids, rhodanine, synthesis, antitrypanosomal activity, antibacterial activity, antifungal activity, SAR.

\section{Introduction}

4-Thiazolidinone derivatives have been known as a source of drug-like molecules with the studied hypoglycemic, anticancer, anti-inflammatory, antituberculosis and antimicrobial ef- fects [1-3]. The inhibition activity against protozoa such as Trypanosoma ssp. [4-6] or Plasmodium falciparum [7] had been also investigated for thiazole/thiazolidinone- and re-

(C) 2020 A. P. Kryshchyshyn-Dylevych; Published by the Institute of Molecular Biology and Genetics, NAS of Ukraine on behalf of Biopolymers and Cell. This is an Open Access article distributed under the terms of the Creative Commons Attribution License (http://creativecommons.org/licenses/by/4.0/), which permits unrestricted reuse, distribution, and reproduction in any medium, provided the original work is properly cited 
lated heterocycles-based compounds. 2,4-Thiazolidinedione, rhodanine (2-thioxo4-thiazolidinone), 2-alkyl(aryl)-substituted, and 2-R-amino(imino)-substituted 4-thiazolidinone subtypes provide the major part of antimicrobial, antidiabetic, anti-inflammatory and anticancer lead-compounds and drug candidates [1,8,9]. 5-Ene-thiazolidinones including the 4-thiazolidinone-3-carboxylic acids derivatives $[10,11]$ are of special interest taking into account their pharmacological profiles, the feasibility of structure optimization as well as the toxicity profile $[12,13]$. Despite falling out of favor with medicinal chemists, 5-ene4-thiazolidinones should not be treated as panassay interference compounds (PAINS) only [14] and still hold a promise for providing active drug-like molecules [15]. One more direction of the 5-ene-4-thiazolidinones study is the search for novel antibacterial agents [16], great part of which comprise rhodanine-3-carboxylic acids.

On the one hand, antibacterial drugs have been saving millions of lives since the discovery of penicillin, but on the other hand, their extensive usage had pushed the antibio- tic resistance mechanisms in bacteria. Surviving of species with such mechanisms challenges therapeutic options of the infectious diseases treatment [17], which needs new classes of antibiotics based on the chemical structures different from those used today. The development of novel safe and efficacious antibacterials remains the topical task of medicinal chemistry and health care system worldwide. Reviewing the latest literature data, it should be mentioned that a class of 5-ene-2-thioxo-4-thiazolidininone-3-carboxylic acids is characterized as a source of agents with excellent antimicrobial activity including MDR strains. For example, 3- $\alpha$-carboxyethyl-5-benzylidenerhodanine derivatives showed moderate to good MIC values against MRSA pathogen panel [18]; a series of 5-(2-hydroxybenzylidene)-rhodanines possessed the MIC values in 32-256 $\mu \mathrm{g} /$ $\mathrm{mL}$ range against $S$. aureus, E. faecalis, and $H$. influenza and were experimentally characterized as novel inhibitors of bacterial DNA gyrase [19]; para- $N, N$-benzylidenediphenylamine substituted rhodanine-3-alkanecarboxylic acids were active against Gram<smiles>CC(C(=O)O)N1C(=O)/C(=C/c2ccccc2[N+](=O)[O-])SC1=S</smiles>

[18]

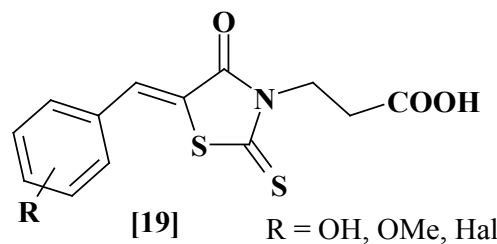

[19]<smiles>[R]N([R])c1ccc(/C=C2\SC(=S)N(CC(=O)O)C2=O)cc1</smiles><smiles>[R4][CH]C(C([R])C([R])C)N1C(=O)/C(=C/c2ccc(/C=N/NC(=O)c3ccccc3)cc2)SC1=S</smiles><smiles>O=C(O)C(Cc1ccccc1)N1C(=O)/C(=C/c2cccc(-c3ccc(Cl)c(Cl)c3)c2)SC1=S</smiles>

Fig. 1. Examples of rhodanine-3-carboxylic acids with the antimicrobial activity. 
(+) pathogens with $\mathrm{MIC}=1.95 \mu \mathrm{g} / \mathrm{mL}[20]$. Rhodanine-3-carboxylic acids with an arylhydrazone fragment displayed the excellent activity against MDR methicillin-resistant and quinolone-resistant $S$. aureus with MIC of $2-4 \mu \mathrm{g} \mathrm{mL} L^{-1}$ [21].

With a broad exposure to antibiotics and immunosuppression, the incidence of opportunistic fungal pathogens such as Candida albicans has increased [22,23]. The compounds revealing antifungal activity are also presented among 2-thioxo-4-thiazolidinones. A derivative of 2-(rhodanine-3-yl)-3-phenylpropanoic acid showed the micromolar ranges of MIC towards the isolates of Gram $(+)$ and Gram (-) bacteria including the vancomycin resistant strains as well as Candida albicans and was not toxic to mouse murine macrophages and human keratinocytes [24]. Taking into account the literature data on antibacterial, antifungal and antiparasitic properties of thiazolidinone derivatives, the feasibility of their synthesis and further chemical optimization, the aim of presented research was the design of potentially active antimicrobials on the base of rhodanine-3-carboxylic acids.

\section{Materials and Methods}

\section{Chemistry}

All chemicals were of the analytical grade and commercially available. All reagents and solvents were used without further purification and drying. NMR spectra were determined with Varian Mercury 400 (400 MHz) spectrometer, in DMSO- $d_{6}$ using tetramethylsilane as an internal standard. Elemental analyses $(\mathrm{C}$, $\mathrm{H}, \mathrm{N}$ ) were performed at the Perkin-Elmer $2400 \mathrm{CHN}$ analyzer and the results were with- in $\pm 0.4 \%$ of the theoretical values. Mass spectra were obtained using electrospray ionization (ESI) techniques on an Agilent 1100 Series LCMS. The purity of the compounds was checked by thin-layer chromatography performed with Merck Silica Gel 60 F254 aluminum sheets.

Synthesis of ethyl 3-(4-oxo-2-thioxothiazolidin-3-yl)propanoate (Ic). The 3-(4-oxo2-thioxothiazolidin-3-yl)propanoic acid (0.1 mole) was refluxed in the ethanol medium (200 $\mathrm{mL}$ ) with adding catalytic amounts of concentrated sulfuric acid for 5 hours. After cooling the reaction mixture to the room temperature, it was neutralized with potassium carbonate to pH 7.0 and the formed precipitate (potassium sulfate) was filtered off. The obtained filtrate was evaporated under vacuo to yield the product as viscous yellow liquid that was used in further reactions without additional purification.

General procedure of 5-(ethoxymethylene)4-oxo-2-thioxothiazolidin-3-carboxylic acids (IIa, IIb) and ethyl 3-[5-(ethoxymethylene)-4-oxo-2-thioxothiazolidin-3-yl]propanoate (IIc) synthesis

A mixture of 4-oxo-2-thioxothiazolidine3 -acetic acid ( 0.1 mole), ethyl orthoformate $(0.12 \mathrm{~mole})$ and $125 \mathrm{ml}$ of acetic anhydride was refluxed for 1.5 hour. After cooling, the reaction mixture was concentrated and small amount of chloroform was added to cause the precipitate formation. The precipitate was filtered off and recrystallized from ethyl acetate to give 5-(ethoxymethylene)-4-oxo-2-thioxothiazolidine-3-acetic acid [25].

In the case of IIb and IIc synthesis, a mixture of 4-oxo-2-thioxothiazolidine-3-propanoic acid or its ethyl ester $(0.1 \mathrm{~mol})$, ethyl ortho- 
formate $(0.12 \mathrm{~mol})$ and $40-50 \mathrm{ml}$ of acetic anhydride was refluxed for 1.5 hour. The reaction mixture was poured into water and the product was extracted with ethylacetate. The ethylacetate layer was evaporated under vacuo and the obtained solid product was recrystallized at first from the mixture of acetic acid/ water with the second recrystallization from the mixture of toluene/hexane for IIb (method A) or from ethanol only for IIc. Purification of the mixture of products after the first crystallization (acetic acid/water) by column chromatography was performed in the system of solvents: aceton/hexane $/ \mathrm{NH}_{4} \mathrm{OH}=50: 50: 1$.

2-[5-(Ethoxymethylene)-4-oxo-2thioxothiazolidin-3-yl]acetic acid (IIa). Yield $61 \%$, mp $188-189{ }^{\circ} \mathrm{C}$, lit. $190-192{ }^{\circ} \mathrm{C}$ [25]. ${ }^{1} \mathrm{H}$ NMR (DMSO- $\left.d_{6}\right) d: 1.25\left(\mathrm{t}, 3 \mathrm{H}, \mathrm{CH}_{3}\right)$, 4.18 (q, 2H, CH), 4.41 (s, 2H, $\left.\mathrm{CH}_{2} \mathrm{COO}\right), 7.58$ (s, $1 \mathrm{H},-\mathrm{CH}=$ ). Calcd. for $\mathrm{C}_{8} \mathrm{H}_{9} \mathrm{NO}_{4} \mathrm{~S}_{2}: \mathrm{C}$, 38.86; H, 3.67; N, 5.66; Found: C, 39.35; H, $3.74 ; \mathrm{N}, 5.61$.

3-[5-(Ethoxymethylene)-4-oxo-2-thioxothiazolidin-3-yl]propanoic acid (IIb). Yield $85 \%$, mp 113-115 ${ }^{\circ} \mathrm{C} .{ }^{1} \mathrm{H}$ NMR (DMSO- $d_{6}$ ) d: $1.28\left(\mathrm{t}, 3 \mathrm{H}, \mathrm{CH}_{2} \mathrm{CH}_{3}\right), 1.81\left(\mathrm{t}, 1 \mathrm{H}, \mathrm{CH}_{2}\right)$, $2.28\left(\mathrm{t}, 1 \mathrm{H}, \mathrm{CH}_{2}\right), 3.96\left(\mathrm{t}, 2 \mathrm{H}, \mathrm{CH}_{2}\right), 4.36(\mathrm{q}$, $\left.2 \mathrm{H}, \mathrm{CH}_{2} \mathrm{CH}_{3}\right), 7.99(\mathrm{~s}, 2 \mathrm{H}, \mathrm{CH}=), 12.01(\mathrm{~s}$, $1 \mathrm{H}, \mathrm{COOH})$. LCMS (ESI+): $\mathrm{m} / z 262.0$ $\left(96.6 \%,[\mathrm{M}+\mathrm{H}]^{+}\right)$.

Calcd. for $\mathrm{C}_{9} \mathrm{H}_{19} \mathrm{NO}_{4} \mathrm{~S}_{2}: \mathrm{C}, 41.37 ; \mathrm{H}, 4.24$; N, 5.36; Found: C, 41.25; H, 4.24; N, 5.34.

Ethyl 3-[5-(ethoxymethylene)-4-oxo2-thioxothiazolidin-3-yl]propanoate (IIc). Yield $87 \%$, mp $111-113^{\circ} \mathrm{C} .{ }^{1} \mathrm{H}$ NMR $\left(\mathrm{DMSO}-d_{6}\right) d: 1.15-1.17\left(\mathrm{~m}, 3 \mathrm{H}, \mathrm{CH}_{2} \mathrm{CH}_{3}\right)$, $1.28\left(\mathrm{t}, 3 \mathrm{H}, \mathrm{CH}_{3}\right), 2.64-2.66\left(\mathrm{~m}, 2 \mathrm{H}, \mathrm{CH}_{2}\right)$, 4.03 (q, 2H, $\left.\mathrm{CH}_{2} \mathrm{CH}_{3}\right), 4.19$ (t, $\left.2 \mathrm{H}, \mathrm{CH}_{2}\right), 4.30$ (q, $\left.2 \mathrm{H}, \mathrm{CH}_{2}\right), 7.98(\mathrm{~s}, 2 \mathrm{H}, \mathrm{CH}=)$. Calcd. for
$\mathrm{C}_{11} \mathrm{H}_{15} \mathrm{NO}_{4} \mathrm{~S}_{2}: \mathrm{C}, 45.66 ; \mathrm{H}, 5.22 ; \mathrm{N}, 4.84$; Found: C, 41.25; H, 5.19; N, 4.89 .

General procedure of 2-[5-[aminomethylene]-4-oxo-2-thioxothiazolidin-3-yl]carboxylic acids (IIIa-IIId) and their esters (IIIfIIIj) synthesis

To $0.01 \mathrm{~mol}$ of 5-(ethoxymethylene)-4-oxo2-thioxothiazolidin-3-carboxylic acid (IIa or IIb) or ethyl 3-[5-(ethoxymethylene)-4-oxo2-thioxo-thiazolidin-3-yl]propanoate (IIc) the equimolar quantity of appropriate amine (4-(ethoxycarbonyl)aniline, 4-chloroaniline, 4-fluoroaniline or 4-(6-methyl-1,3-benzothiazol-2-yl)aniline), 3/4-aminopyridines or 4-pyridinecarboxylic acid hydrazide) was added and refluxed in the ethanol medium for 1.5-2 hours. After cooling, the formed precipitate was filtered off and recrystallized from the mixture of acetic acid/water (1:1) (IIIa) or acetic acid (IIIb, IIIc, IIIg) or the mixture of DMF/ethanol (1:3) (IIId, IIIh-IIIj), or ethanol (IIIf).

2-[5-[(4-Ethoxycarbonylanilino)methylene]4-oxo-2-thioxothiazolidin-3-yllacetic acid (IIIa). Yield $55 \%$, mp $170-172^{\circ} \mathrm{C} .{ }^{1} \mathrm{H}$ NMR $\left(\mathrm{DMSO}-d_{6}\right) d: 1.28\left(\mathrm{t}, 3 \mathrm{H}, \mathrm{CH}_{2} \mathrm{CH}_{3}, J=6.9 \mathrm{~Hz}\right)$, 4.25 (q, $\left.2 \mathrm{H}, \mathrm{CH}_{2} \mathrm{CH}_{3}\right), 4.63$ (s, $\left.2 \mathrm{H}, \mathrm{CH}_{2}\right), 7.39$ (d, $2 \mathrm{H}, J=8.2 \mathrm{~Hz}$, arom.), $7.91(\mathrm{~d}, 2 \mathrm{H}$, $J=8.2 \mathrm{~Hz}$, arom.), 8.36 (d, 1H, $\mathrm{CH}=), 10.57$ (д, $1 \mathrm{H}) .{ }^{13} \mathrm{C}$ NMR $\left(100 \mathrm{MHz}, \mathrm{DMSO}-d_{6}\right): 191.9$, 168.1, 166.7, 165.6, 144.4, 135.1, 131.4, 131.3, 125.0, 116.6, 113.0, 96.7, 60.9, 45.2, 14.6. LCMS (ESI+): $\left.m / z 367.0(98.2 \% \text {, [M+H] }]^{+}\right)$. Calcd. for $\mathrm{C}_{15} \mathrm{H}_{14} \mathrm{~N}_{2} \mathrm{O}_{5} \mathrm{~S}_{2}: \mathrm{C}, 49.17 ; \mathrm{H}, 3.85 ; \mathrm{N}$, 7.65; Found: C, 49.87; H, 3,92; N, 7.50.

3-[5-[(4-Ethoxycarbonylphenylamino) methylene]-4-oxo-2-thioxothiazolidin-3-yl] propanoic acid (IIIb). Yield 57 \%, mp 192$193^{\circ} \mathrm{C} .{ }^{1} \mathrm{H}$ NMR (DMSO- $d_{6}$ ) d: 1.30 (brs, $3 \mathrm{H}$, $\left.\mathrm{CH}_{2} \mathrm{CH}_{3}\right), 2.67\left(\mathrm{t}, 2 \mathrm{H}, \mathrm{CH}_{2}\right), 4.05-4.18(\mathrm{~m}, 2 \mathrm{H}$, 
$\left.\mathrm{CH}_{2}\right), 4.26\left(\mathrm{q}, 2 \mathrm{H}, \mathrm{CH}_{2} \mathrm{CH}_{3}\right), 7.48(\mathrm{~m}, 2 \mathrm{H}$, arom.), 7.92 (m, 2H, arom.), $8.15(\mathrm{~s}, 1 \mathrm{H}$, $\mathrm{CH}=) .{ }^{13} \mathrm{C}$ NMR $\left(100 \mathrm{MHz}, \mathrm{DMSO}-d_{6}\right): 191.2$, $170.8,165.7,162.6,141.9,136.4,131.4(2 \mathrm{H}$, arom.), 124.7, 117.0 (2H, arom.), 98.1, 61.0, 50.6, 31.6, 14.7. Calcd. for $\mathrm{C}_{16} \mathrm{H}_{16} \mathrm{~N}_{2} \mathrm{O}_{5} \mathrm{~S}_{2}$ : C, 50.51; H, 4.24; N, 7.36; Found: C, 51,00; H, $4.19 ; \mathrm{N}, 7.39$.

3-[5-[(4-Chlorophenylamino)methylene]4-oxo-2-thioxothiazolidin-3-yl]propanoic acid (IIIc). Yield $84 \%, \mathrm{mp} 208-210^{\circ} \mathrm{C} .{ }^{1} \mathrm{H}$ NMR (DMSO- $d_{6}$ ) d: 2.48-2.54 (m, 2H, $\left.\mathrm{CH}_{2}\right), 4.02-4.13$ (m, 2H, $\mathrm{CH}_{2}$ ), 7.28-7.31 (m, 4H, arom.), 7.98 (s, $1 \mathrm{H}, \mathrm{CH}=) .{ }^{13} \mathrm{C}$ NMR $\left(100 \mathrm{MHz}, \mathrm{DMSO}-d_{6}\right)$ : 191.4, 172.3, 166.9, 139.6, 135.9, 135.9, 129.9, 128.2, 118.9, 118.9, 97.6, 95.3, 31.5. LCMS (ESI+): $m / z$ 343.0/345.0 (96.6\%, [M+H] $\left.]^{+}\right)$. Calcd. for $\mathrm{C}_{13} \mathrm{H}_{11} \mathrm{ClN}_{2} \mathrm{O}_{3} \mathrm{~S}_{2}$ : C, 45.55; $\mathrm{H}, 3.23$; N, 8.17; Found: C, 45,83; H, 3.28; N, 8.09.

3-[(5Z)-5-[[4-(6-methyl-1,3-benzothiazol2-yl)anilino]methylene]-4-oxo-2-thioxo-thiazolidin-3-yl]propanoic acid (IIId). Yield $85 \%$, mp $229-230^{\circ} \mathrm{C} .{ }^{1} \mathrm{H}$ NMR (DMSO- $d_{6}$ ) $d: 2.44$ (s, 3H, CH3), 2.58 (t, 2H, CH2), $4.18(\mathrm{t}, 2 \mathrm{H}$, $\mathrm{CH} 2), 7.33$ (d, 1H, J = 7.3 Hz, arom.), 7.45 (d, $2 \mathrm{H}, \mathrm{J}=7.1 \mathrm{~Hz}$, arom.), 7.84-7.90 (m, $2 \mathrm{H}$, arom.), 8.01 (d, 2H, J = 7.1 Hz, arom.), 8.13 $(\mathrm{s}, 1 \mathrm{H},=\mathrm{CH}), 10.52$ (br.s, $1 \mathrm{H}, \mathrm{NH}), 12.52$ (br.s, $1 \mathrm{H}, \mathrm{COOH}) .{ }^{13} \mathrm{C}$ NMR (100 MHz, DMSO- $\left.d_{6}\right)$ : 191.6, 172.3, 167.0, 165.9, 152.3, 142.9, 135.6, $134.8,134.9,129.0,128.6,128.5,122.7,122.2$, 117.4 (2H, arom.), 101.2, 96.5, 49.7, 31.5, 21.6. LCMS (ESI+): LCMS (ESI+): $m / z 456.0$ $\left(98.1 \%,[\mathrm{M}+\mathrm{H}]^{+}\right)$. Calcd. for $\mathrm{C}_{21} \mathrm{H}_{17} \mathrm{~N}_{3} \mathrm{O}_{3} \mathrm{~S}_{3}$ : C, 55.36; H, 3.76; N, 9.22; Found: C, 55.69; H, 3.81; N, 9.15.

Ethyl 3-[5-[(4-(fluorophenylamino) methylene]-4-oxo-2-thioxothiazolidin-3-yl] propanoate (IIIf). Yield $50 \%, \mathrm{mp} 164-165^{\circ} \mathrm{C}$.
${ }^{1} \mathrm{H}$ NMR (DMSO- $\left.d_{6}\right) d: 1.16-1.18(\mathrm{~m}, 3 \mathrm{H}$, $\mathrm{CH}_{2} \mathrm{CH}_{3}$ ), 2.63-2.66 (m, 2H, $\mathrm{CH}_{2}$ ), 4.04 (q, $\left.2 \mathrm{H}, \mathrm{CH}_{2} \mathrm{CH}_{3}\right), 4.21$ (t, $2 \mathrm{H}, \mathrm{CH}_{2}, J=7.2 \mathrm{~Hz}$ ), 7.19-7.22 (m, 2H, arom.), 7.33-7.37 (m, $2 \mathrm{H}$, arom.), 8.06 (brs, $2 \mathrm{H}, \mathrm{CH}=$ ). ${ }^{13} \mathrm{C} \mathrm{NMR}$ $\left(100 \mathrm{MHz}, \mathrm{DMSO}-d_{6}\right): 192.0,168.1,166.7$, 165.7, 144.5, 135.3, 131.4 (2H, arom.), 125.1, 116.7 (2H, arom.), 96.7, 61.0, 45.3, 14.7. LCMS (ESI+): $\left.m / z 355.0(99.6 \% \text {, [M+H] }]^{+}\right)$. Calcd. for $\mathrm{C}_{15} \mathrm{H}_{15} \mathrm{FN}_{2} \mathrm{O}_{3} \mathrm{~S}_{2}$ : C, 50.83; H, 4.27; N, 7.90; Found: C, 51.05; H, 4.35; N, 7.94.

Ethyl 3-\{5-[(Z)-1-(4-ethyloxycarbonylphemylamino)methylidene]-4-oxo-2-thioxothiazolidin-3-yl\}propanoate (IIIg). Yield 45 $\%$, mp 160-162 ${ }^{\circ} \mathrm{C} .{ }^{1} \mathrm{H}$ NMR (DMSO- $d_{6}$ ) $d$ : 1.16 (brs, $3 \mathrm{H}, \mathrm{CH}_{2} \mathrm{CH}_{3}$ ), 1.30 (brs, $3 \mathrm{H}$, $\mathrm{CH}_{2} \mathrm{CH}_{3}$ ), 2.64 ( $\mathrm{t}, 2 \mathrm{H}, \mathrm{CH}_{2}$ ), 4.05 ( $\mathrm{t}, 2 \mathrm{H}, \mathrm{CH}_{2}$ ), 4.18 (q, $\left.2 \mathrm{H}, \mathrm{CH}_{2} \mathrm{CH}_{3}\right), 4.28$ (q, $2 \mathrm{H}, \mathrm{CH}_{2} \mathrm{CH}_{3}$ ), 7.38 (m, 2H, arom.), 7.91 (m, 2H, arom.), 8.16 (s, $1 \mathrm{H}, \mathrm{CH}=) .{ }^{13} \mathrm{C}$ NMR $\left(100 \mathrm{MHz}, \mathrm{DMSO}-d_{6}\right)$ : $191.7,171.5,165.7,163.6,141.9,136.1131 .4$ $(2 \mathrm{H}$, arom. $), 129.0,124.7,116.9$ (2H, arom.), 61.1, 60.8, 50.3, 32.1, 14.7, 14.1. LCMS (ESI+): $m / z 409.0\left(98.6 \%,[\mathrm{M}+\mathrm{H}]^{+}\right)$. Calcd. for $\mathrm{C}_{18} \mathrm{H}_{20} \mathrm{~N}_{2} \mathrm{O}_{5} \mathrm{~S}_{2}: \mathrm{C}, 52.92 ; \mathrm{H}, 4.93 ; \mathrm{N}, 6.86$; Found: C, 52.63; H, 4.86; N, 6.89 .

Ethyl 3-[4-oxo-5-[(3-pyridylamino) methylenel-2-thioxothiazolidin-3-yl]propanoate (IIIh). Yield $69 \%, \mathrm{mp} 193-195^{\circ} \mathrm{C}$, lit. 192-194 ${ }^{\circ} \mathrm{C}[26] .{ }^{1} \mathrm{H}$ NMR (DMSO- $d_{6}$ ) $d: 2.55$ (t, $3 \mathrm{H}, J=6.8 \mathrm{~Hz}, \mathrm{CH}_{3}$ ), 3.01 (q, $2 \mathrm{H}, J=6.8 \mathrm{~Hz}$, $\left.\mathrm{OCH}_{2}\right), 3.75\left(\mathrm{t}, 2 \mathrm{H}, \mathrm{CH}_{2}, J=6.9 \mathrm{~Hz}\right), 5.50(\mathrm{q}$, $2 \mathrm{H}, \mathrm{CH}_{2}, J=6.9 \mathrm{~Hz}$ ), 7.34 (brs, $1 \mathrm{H}$, pyrid.), 7.66 (d, $1 \mathrm{H}, J=7.9 \mathrm{~Hz}$, pyrid.), 7.73 (s, 1H, pyrid.), 7.80 (d, $1 \mathrm{H}, J=7.3 \mathrm{~Hz}$, pyrid.), 7.83 (brs, $1 \mathrm{H}, \mathrm{CH}=), 10.42$ (s, 1H, NH). ${ }^{13} \mathrm{C}$ NMR (100 MHz, DMSO- $\left.d_{6}\right)$ : 193.7, 172.1, 167.2, 145.8, 144.7, 139.6, 133.1, 129.3, 123.7, 114.5, 60.7, 49.8, 32.2, 14.1. Calcd. for $\mathrm{C}_{14} \mathrm{H}_{15} \mathrm{~N}_{3} \mathrm{O}_{3} \mathrm{~S}_{2}$ : 
C, 49.83; H, 4.48; N, 12.45; Found: C, 50.02; $\mathrm{H}, 4.42 ; \mathrm{N}, 12.35$.

Ethyl 3-I(4-oxo-5-I(4-pyridylamino) methylene]-2-thioxothiazolidin-3-yl]propanoate (III). Yield $45 \%$, mp $182-184^{\circ} \mathrm{C}$ lit. $183-$ $185^{\circ} \mathrm{C}[26] .{ }^{1} \mathrm{H}$ NMR (DMSO- $\left.d_{6}\right) d: 1.16$ (t, $3 \mathrm{H}, \mathrm{CH}_{3}, J=7.0 \mathrm{~Hz}$ ), 2.60 (q, $2 \mathrm{H}, \mathrm{OCH}_{2}, J=$ $7.0 \mathrm{~Hz}), 4.00$ (t, 2H, $\left.\mathrm{CH}_{2}, J=7.3 \mathrm{~Hz}\right), 4.19$ (t, $\left.2 \mathrm{H}, \mathrm{CH}_{2}, J=7.3 \mathrm{~Hz}\right), 6.71(\mathrm{~d}, 2 \mathrm{H}, J=6.9 \mathrm{~Hz}$, pyrid.), 7.57 (s, $1 \mathrm{H}, \mathrm{CH}=), 8.07(\mathrm{~d}, 2 \mathrm{H}, J=$ $6.9 \mathrm{~Hz}$, pyrid.), 10.41 (brs, $1 \mathrm{H}, \mathrm{NH}) .{ }^{13} \mathrm{C}$ NMR (100 MHz, DMSO- $\left.d_{6}\right)$ : 192.6, 171.6, 166.5, 149.8 (2H, arom.), 140.1, 132.8, 129.1, 118.1 (2H, arom.), 60.9, 49.5, 32.3, 14.1. Calcd. for $\mathrm{C}_{14} \mathrm{H}_{15} \mathrm{~N}_{3} \mathrm{O}_{3} \mathrm{~S}_{2}$ : C, 49.83; H, 4.48; N, 12.45; Found: C, 49.80; H, 4.46; N, 12.38 .

Ethyl 3-I(4-oxo-5-I[2-(pyridine-4-carbonyl)hydrazino/methylenel-2-thioxothiazolidin3-yllpropanoate (IIIj). Yield 73 \%, mp 235$237^{\circ} \mathrm{C}[26] .{ }^{1} \mathrm{H}$ NMR (DMSO- $d_{6}$ ) $d: 1.15$ (t, $3 \mathrm{H}, \mathrm{CH}_{3}, J=7.1 \mathrm{~Hz}$ ), 2.60 (t, $2 \mathrm{H}, \mathrm{CH}_{2}, J=7.1$ $\mathrm{Hz}), 4.02$ (q, 2H, $\left.\mathrm{CH}_{2}, J=7.1 \mathrm{~Hz}\right), 4.16(\mathrm{t}$, $\left.2 \mathrm{H}, \mathrm{CH}_{2}, J=7.1 \mathrm{~Hz}\right), 7.85(\mathrm{~m}, 3 \mathrm{H}, \mathrm{CH}=$, pyrid.), 8.84 (brs, $2 \mathrm{H}$, pyrid.), 10.27 (brs, $1 \mathrm{H}$, $\mathrm{NH}), 11.40$ (brs, $1 \mathrm{H}, \mathrm{NH}) .{ }^{13} \mathrm{C}$ NMR $(100 \mathrm{MHz}$, DMSO- $\left.d_{6}\right)$ : $192.3,172.2,170.7,167.1,164.8$, $150.8(2 \mathrm{H}$, arom. $), 139.6,131.2,121.8(2 \mathrm{H}$, arom.), 89.8, 60.7, 31.5, 14.4. Calcd. for $\mathrm{C}_{15} \mathrm{H}_{16} \mathrm{~N}_{4} \mathrm{O}_{4} \mathrm{~S}_{2}$ : C, 47.36; H, 4.24; N, 14.73; Found: C, 47.56; H, 4.26; N, 14.77.

Method of the ethyl 3-/5-(aminomethylene)4-oxo-2-thioxothiazolidin-3-yl]propanoate (IIIe) synthesis

The mixture of equimolar amounts of ethyl 3-[5-(ethoxymethylene)-4-oxo-2-thioxo-thiazolidin-3-yl]propanoate IIc and ammonium hydrogen carbonate $(0.01 \mathrm{~mol})$ was refluxed in the ethanol medium $(15 \mathrm{~mL})$ for 2 hours. After cooling the reaction mixture, the formed precipitate was filtered off and recrystallized from acetic acid.

Ethyl 3-[5-(aminomethylene)-4-oxo2-thioxo-thiazolidin-3-yl]propanoate (IIIe). Yield $65 \%, \mathrm{mp} 113-115^{\circ} \mathrm{C} .{ }^{1} \mathrm{H}$ NMR $\left(\mathrm{DMSO}-d_{6}\right) d: 1.15\left(\mathrm{t}, 3 \mathrm{H}, \mathrm{CH}_{3}, J=7.1 \mathrm{~Hz}\right.$ ), $2.67\left(\mathrm{t}, 2 \mathrm{H}, \mathrm{CH}_{2} J=7.1 \mathrm{~Hz}\right), 4.08(\mathrm{q}, 2 \mathrm{H}$, $\left.\mathrm{CH}_{2}\right), 4.17\left(\mathrm{~m}, 2 \mathrm{H}, \mathrm{CH}_{2}\right), 8.14(\mathrm{~s}, 1 \mathrm{H}, \mathrm{CH}=)$. ${ }^{13} \mathrm{C}$ NMR (100 MHz, DMSO- $\left.d_{6}\right)$ : 191.9, 172.3, 165.2, 132.4, 129.1, 60.9, 50.3, 32.6, 14.1. Calcd. for $\mathrm{C}_{9} \mathrm{H}_{12} \mathrm{~N}_{2} \mathrm{O}_{3} \mathrm{~S}_{2}: \mathrm{C}, 41.52 ; \mathrm{H}, 4.65 ; \mathrm{N}$, 10.76; Found: C, 41.74; H, 4.72; N, 10.85.

\section{Pharmacology}

Antibacterial and antifungal activity screening

The synthesized compounds were screened for their in vitro antibacterial and antifungal activities using the agar diffusion method and the broth microdilution method (Resazurin Reduction-Based Assay) [27]. A total of 12 microorganisms were tested. They consisted of 4 Gram (-) bacteria: Pseudomonas aeruginosa ATCC 27853 (F-51) and Escherichia coli ATCC 25922 used as reference strains and clinical strains of Pseudomonas aeruginosa and Escherichia coli; 4 Gram $(+)$ bacteria: clinical strains of Staphylococcus lentus, Staphylococcus lugnuniensis, Staphylococcus simulans and the reference strain - Staphylococcus aureus ATCC 25923 (F-49); four yeasts: Candida albicans (ATCC 885-653) used as reference strain, clinical strains of Candida albicans, Candida dubliniensis and Candida membranifaciens. The Clinical and rarely found clinical strains were multidrug resistant [28] and isolated from patients with health-care-associated infections. 
The tested compounds (at the concentration of $1 \mathrm{mM}$ ) were inoculated into a $5.5 \pm 0.5 \mathrm{~mm}$ diameter well $(50 \mu \mathrm{L}$ per well) containing suspension of the culture of microorganisms (McFarland 2.0) on the agar plate (meat peptone agar or Saburo agar for fungi). DMSO was used as a control. A compound with the diameter of growth inhibition more than $10 \mathrm{~mm}$ was considered as a hit-compound [27].

\section{Antitrypanosomal activity screening}

Bloodstream forms of Trypanosoma brucei brucei strain 90-13 and Trypanosoma brucei gambiense Feo strain were cultured in HMI9 medium supplemented with $10 \% \mathrm{FCS}$ at $37{ }^{\circ} \mathrm{C}$ in an atmosphere of $5 \% \mathrm{CO}_{2}$ [29]. In all experiments, log-phase cell cultures were harvested by centrifugation at $3000 \times \mathrm{g}$ and immediately used. Drug assays were based on the conversion of a redox-sensitive dye (resazurin) to a fluorescent product by viable cells [30]. Drug stock solutions were prepared in DMSO. Trypanosoma brucei bloodstream forms $\left(10^{5}\right.$ cells $/ \mathrm{mL}$ ) were cultured in 96-well plates either in the absence or in the presence of different concentrations of inhibitors in a final volume of $200 \mathrm{~mL}$. After the $72 \mathrm{~h}$ incubation, resazurin solution was added in each well at the final concentration of $45 \mathrm{mM}$ and fluorescence was measured at $530 \mathrm{~nm}$ and $590 \mathrm{~nm}$ absorbance after further $4 \mathrm{~h}$ incubation. The percentage of inhibition of the parasite growth rate was calculated by comparing the fluorescence of parasites maintained in the presence of drug to that in the absence of drug. DMSO was used as a control. The concentration inhibiting $50 \%$ of parasite growth $\left(\mathrm{IC}_{50}\right)$ was given as the mean $+/$ - the standard deviation of three independent experiments.

\section{Results and Discussion}

\section{Chemistry}

The synthesis of 3-carboxyalkylrhodanines (Scheme 1) was conducted according to the modified procedure proposed by Körner [31] from glycine or $\beta$-alanine and $\mathrm{CS}_{2}$ in an alkaline medium. The next step involved [2+3]-cyclocondensation of formed dithiocarbamates ( $S, N$-binucleophiles) with chloroacetic acid (equivalent to dielectrophilic synton $\left[\mathrm{C}_{2}\right]^{2+}$ ) and yielded the corresponding 2-thioxo-4-thiazolidone-3-alkancarboxylic acids. Synthesis of 5-ethoxymethylidene derivatives II was performed in the reaction of rhodanine-3-carboxylic acids Ia-b and ethyl ester Ic with triethyl orthoformate in the acetic anhydride medium. There was observed the formation of the mixture of ethyl 3-[5-(ethoxymethylene)4-oxo-2-thioxothiazolidin-3-yl]propanoate and an acid itself unlike in the same reaction of rhodanine-3-phenylpropionic acid, when only ethyl ester of 2-(5-ethoxymethylidene-2-(4oxo-2-thioxo-thiazolidine-3-yl)-3-phenyl-propionic acid was formed [32]. Therefore, besides the method of column chromatography, to obtain pure compound IIc, an ethyl 3-(4-oxo-2-thioxothiazolidin-3-yl)propanoate Ic (synthesized in the reaction of esterification) was used as a starting agent in the reaction with triethyl orthoformate.

The 5-ethoxymethylenerhodanines can easily react with the $N$-nucleophilic reagents as primary or secondary amines. Thus, the target compounds IIIa-IIId, IIIf-IIIg were synthesized in the reactions of 5-(ethoxymethylene)4-oxo-2-thioxothiazolidin-3-carboxylic acids IIa,b and ethyl 3-[5-(ethoxymethylene)-4-oxo2-thioxothiazolidin-3-yl]propanoate IIc with 
appropriate amines, such as 4-(ethoxycarbonyl)aniline, halogen-substituted anilines and 4-(6-methyl-1,3-benzothiazol-2-yl)aniline. The reaction of IIc with ammonium hydrogen carbonate in the ethanol medium yielded ethyl 3-[5-(aminomethylene)-4-oxo-2-thioxothiazolidin-3-yl]propanoate (IIIe). To analyze the structure-activity relationship in this series of compounds the pyridine fragment was intro- duced in the aminomethylene group via the reaction of ethyl 3-[5-(aminomethylene)4-oxo-2-thioxothiazolidin-3-yl]propanoate IIc with aminopyridines and 4-pyridinecarboxylic acid hydrazide.

\section{Antibacterial and antifungal activity}

Five of the synthesized compounds III were tested towards a series of Gram (+) and Gram

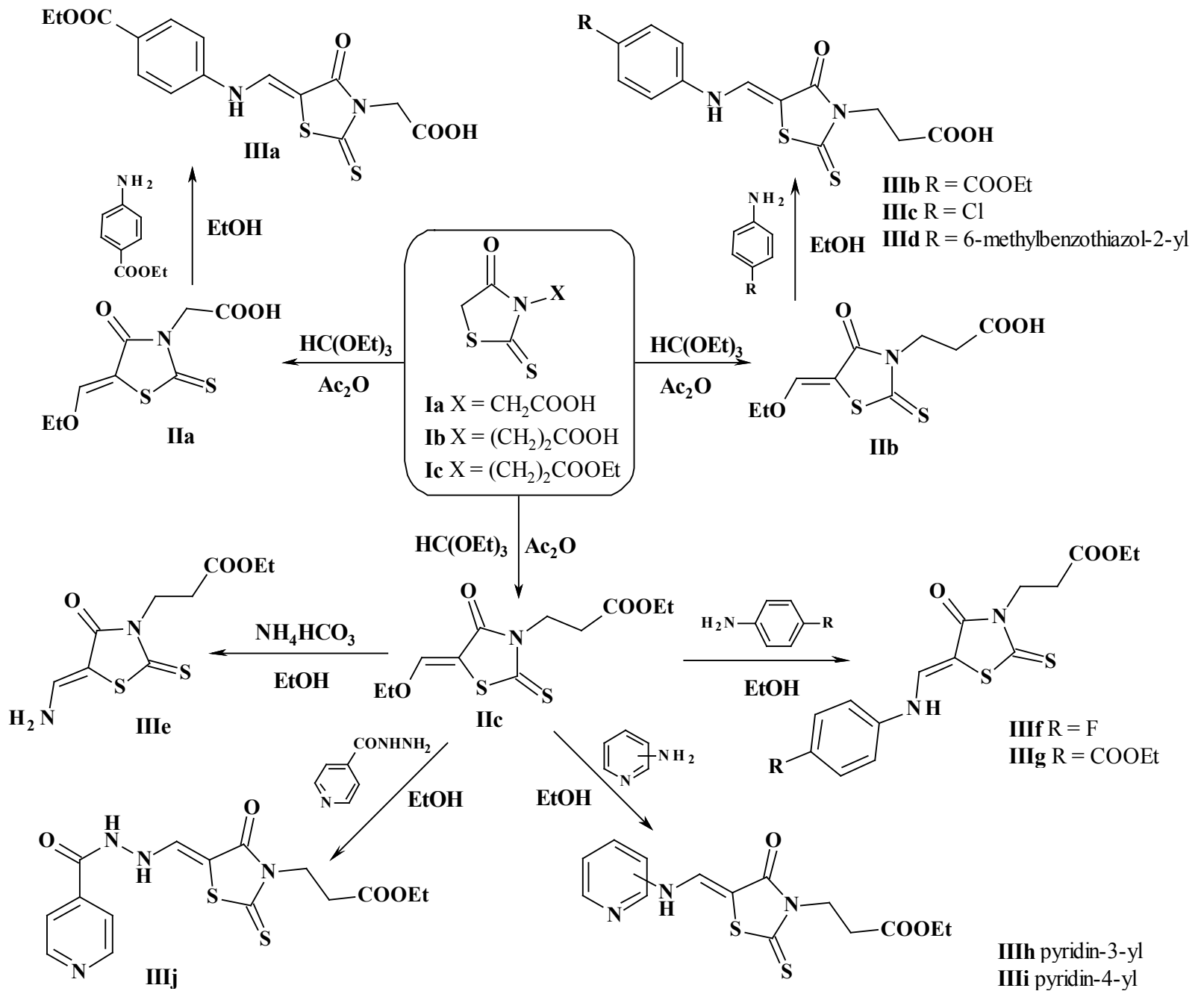

Scheme 1. Synthesis of 5-substituted derivatives of 2-(4-oxo-2-thioxothiazolidin-3-yl)-3-acetic and propanoic acid. 
(-) bacteria and four yeasts strains (Table 1) at the concentration of $1 \mathrm{mM}(50 \mathrm{mcL}$ per well). The synthesized compounds showed different mean zones of inhibition in the range of $0-15.0 \mathrm{~mm}$ against tested microorganisms. 5-Aminomethylenerhodanine-3-propanoic acid derivatives did not inhibited the growth of Gram (-) bacteria. Only two of the tested compounds IIIb and IIIf were active against clinical strains of Gram (+) Staphylococcus simulans and Staphylococcus lentus respectively. Candida ssp. turned out to be the most sensitive to the action of all studied compounds exhibiting the highest inhibition rates under the action of ethyl 3-[5-[(4-(fluoroanilino) methylene]-4-oxo-2-thioxothiazolidin-3-yl] propanoate IIIf. Substitution of the aryl moiety with pyridine fragment led to the total loss of antibacterial effects, although compounds IIIh-IIIj showed antifungal activity towards reference and clinical Candida strains. In general, the tested compounds are promising building scaffolds for the development of antifungal agents as all of them inhibited the growth of clinical strain of Candida albicans.

An interesting additional research of the pyridine containing compounds IIIh-IIIj was performed against Trypanosoma ssp. (Table 2) that corresponds to the concept of polypharmacological approach [33]. Noteworthy, such small molecules as the studied rhodanine ana$\log$ s hold a privileged position for polypharmacology and may be successfully utilized in the fragment-based drug discovery too $[34,35]$.

Table 1. Antibacterial and antifungal activity of synthesized compounds

\begin{tabular}{|c|c|c|c|c|c|c|c|c|c|c|c|c|}
\hline \multirow[b]{4}{*}{ Comp. } & \multicolumn{12}{|c|}{ Diameter of zone inhibition, $\mathrm{mm}$} \\
\hline & \multicolumn{4}{|c|}{ Gram $(-)$ bacteria } & \multicolumn{4}{|c|}{ Gram $(+)$ bacteria } & \multicolumn{4}{|c|}{ Fungi } \\
\hline & \multicolumn{2}{|c|}{ reference strains } & \multicolumn{2}{|c|}{ clinical strains } & $\begin{array}{c}\text { reference } \\
\text { strain }\end{array}$ & \multicolumn{2}{|c|}{ clinical strains } & $\begin{array}{l}\text { rarely } \\
\text { found } \\
\text { clinical } \\
\text { strains }\end{array}$ & $\begin{array}{l}\text { reference } \\
\text { strain }\end{array}$ & \multicolumn{2}{|c|}{ clinical strains } & $\begin{array}{l}\text { rarely } \\
\text { found } \\
\text { clinical } \\
\text { strain }\end{array}$ \\
\hline & 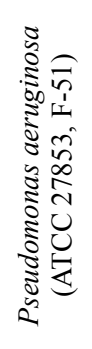 & 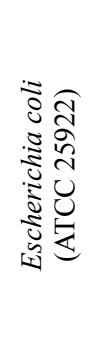 & 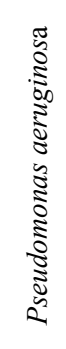 & 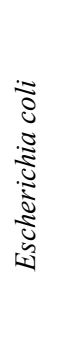 & 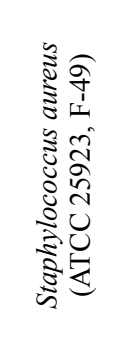 & 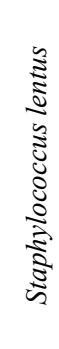 & 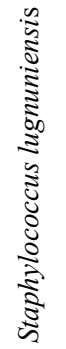 & 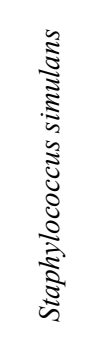 & 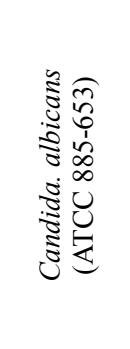 & 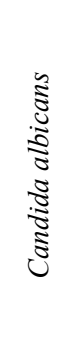 & 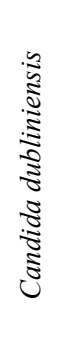 & 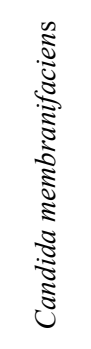 \\
\hline IIIb & 9 & 0 & NT & 0 & 0 & 0 & 0 & 10 & 8 & 12 & 0 & 10 \\
\hline IIIf & 0 & 0 & NT & 0 & 0 & 10 & 0 & 0 & 7 & 15 & 11 & 10 \\
\hline IIIh & 0 & 0 & 0 & 0 & 0 & 0 & 0 & 0 & 0 & 10 & 0 & 0 \\
\hline IIII & 0 & 0 & 0 & 0 & 0 & 0 & 0 & 0 & 12 & 10 & 0 & 0 \\
\hline IIIj & 0 & 0 & NT & 0 & 0 & 0 & 0 & 0 & 0 & 10 & 0 & 10 \\
\hline DMSO & 0 & 0 & 0 & 0 & 0 & 0 & 0 & 0 & 10 & 7 & 10 & 10 \\
\hline
\end{tabular}


Table 2. Antitrypanosomal activity of ethyl 3-[4-oxo-5-aminomethylene]-2-thioxothiazolidin-3-yl] propanoates IIIh-IIIj

\begin{tabular}{l|c|c|c|c|c}
\hline & $\begin{array}{c}\text { Trypanosoma brucei } \\
\text { brucei } \\
\mathrm{IC}_{50}, \mu \mathrm{M}\end{array}$ & $\begin{array}{c}\text { Trypanosoma brucei } \\
\text { gambiense } \\
\mathrm{IC}_{50}, \mu \mathrm{M}\end{array}$ & $\begin{array}{c}\text { Cytotoxicity on fibroblast } \\
\mathrm{CC}_{50}, \mu \mathrm{M}\end{array}$ & SI/Tbb & SI/Tbg \\
\hline IIIh & $19.19 \pm 6.33$ & $5.03 \pm 1.85$ & $182.41 \pm 12.36$ & 9.5 & 36.2 \\
\hline IIIi & $>148$ & $21.04 \pm 0.42$ & $155.00 \pm 29.33$ & $<1$ & 7.4 \\
\hline IIIj & $>131$ & $71.89 \pm 19.52$ & $>262$ & 1,0 & $>3.6$ \\
\hline Pentamidine,nM & $1.36 \pm 0.46$ & $1.46 \pm 0.65$ & $7900.00 \pm 282.84$ & 5793.9 & 5396.9 \\
\hline Nifurtimox & $2.39 \pm 0.61$ & $4.64 \pm 0.73$ & $65.09 \pm 2,95$ & 27.2 & 14.0 \\
\hline
\end{tabular}

The best in vitro inhibitory activity of Trypanosoma brucei brucei and Trypanosoma brucei gambiense was observed for ethyl 3-[4-oxo-5-[(3-pyridylamino)methylene]2-thioxothiazolidin-3-yl]propanoate IIIh with the micromolar $\mathrm{IC}_{50}$ values comparable to the reference drugs Pentamidine and Nifurtimox. The selectivity indexes calculated as a ratio of cytotoxic concentration against normal fibroblasts $\mathrm{CC}_{50}$ to the antitrypanosomal $\mathrm{IC}_{50}$ values, indicate very good perspective for the study of rhodanine-3-carboxylic acids as potential antitrypanosomals with low toxicity parameters.

The established dual antitrypanosomal and antifungal actions are consistent with the recently developed new effective oral monotherapy of HAT with antifungal drug Fexinidazole [5].

\section{Conclusions}

A series of novel 3-[5-(aminomethylene)4-oxo-2-thioxo-thiazolidin-3-yl]carboxylic acids and their esters were designed and synthesized starting from 5-ethoxymethylenerhodanine-3-carboxylic acids. Study on the antibacterial action of 5 compounds revealed a significant antifungal activity against the clinical strain of Candida albicans with the most active ethyl 3-[(5Z)-5-[(4-(fluoroanilino) methylene]-4-oxo-2-thioxo-thiazolidin-3-yl] propanoate IIIf. The pyridine-rhodanine-3-carboxylic hybrids showed good ratios of Trypanosoma ssp. inhibition and low cytotoxicity towards human fibroblasts. Such dual action of the rhodanine-3-carboxylic acids derivatives is an important issue that may be used in the polypharmacological approach as well as the fragment-based drug discovery.

\section{Acknowledgement}

I express my sincere gratitude to Prof. Philippe Grellier (National Museum of Natural History, Paris, France) and PhD student Yulian Konechnyi (Department of microbiology, Danylo Halytsky Lviv National Medical University) for the evaluation of biological activity of the synthesized compounds.

\section{REFERENCES}

1. Kaminskyy D, Kryshchyshyn A, Lesyk R. 5-Ene4-thiazolidinones - An efficient tool in medicinal chemistry. Eur J Med Chem. 2017; 140: 542-94. 
2. Havrylyuk D, Roman O, Lesyk R. Synthetic approaches, structure activity relationship and biological applications for pharmacologically attractive pyrazole/pyrazoline-thiazolidine-based hybrids. Eur J Med Chem. 2016; 113: 145-66.

3. Tripathi AC, Gupta SJ, Fatima GN, Sonar PK, Verma A, Saraf SK. 4-Thiazolidinones: The advances continue. Eur J Med Chem. 2014; 72: 52-77.

4. Kryshchyshyn A, Kaminskyy D, Karpenko O, Gzella A, Grellier P, Lesyk R. Thiazolidinone/thiazole based hybrids - New class of antitrypanosomal agents. Eur J Med Chem. 2019; 174: 292-308.

5. Kryshchyshyn A, Kaminskyy D, Grellier P, Lesyk R. Thiazolidinone-Related Heterocyclic Compounds as Potential Antitrypanosomal Agents. In Azoles Synthesis, Properties, Applications and Perspectives. IntechOpen, 2020.

6. da Silva EB, Oliveira e Silva DA, Oliveira AR, da Silva Mendes CH, dos Santos TAR, da Silva AC, de Castro MCA, Ferreira RS, Moreira DRM, Cardoso $M V$ de $O$, de Simone CA, Pereira VRA, Leite ACL. Desing and synthesis of potent anti - Trypanosoma cruzi agents new thiazoles derivatives which induce apoptotic parasite death. Eur J Med Chem. 2017; 130: $39-50$.

7. Kryshchyshyn-Dylevych AP, Zelisko NI, Grellier P, Lesyk RB. Preliminary evaluation of thiazolidinoneand pyrazoline-related heterocyclic derivatives as potential antimalarial agents. Biopolym Cell. 2020; 36(1): 48-60.

8. Tomasic T, Masic L. Rhodanine as a Privileged Scaffold in Drug Discovery. Curr Med Chem. 2009; 16(13): 1596-629.

9. Kaminskyy D, Kryshchyshyn A, Lesyk R. Recent developments with rhodanine as a scaffold for drug discovery. Expert Opin Drug Discov. 2017; 12(12): 1233-52.

10. Kaminskyy D V, Lesyk RB. Structure-anticancer activity relationships among 4-azolidinone-3-carboxylic acids derivatives. Biopolym Cell. 2010; 26(2): 136-45.

11. Kryshchyshyn A, Kaminskyy D, Roman O, Kralovics $R$, Karpenko $O$, Lesyk $R$. Synthesis and antileukemic activity of pyrrolidinedione-thiazolidinone hybrids. Ukr Biochem J. 2020; 92(2): 108-19.
12. Kaminskyy D. A Facile Synthesis and Anticancer Activity Evaluation of Spiro[Thiazolidinone-Isatin] Conjugates. Sci Pharm. 2011; 79(4): 763-77.

13. Lesyk RB, Zimenkovsky BS, Kaminskyy D V., Kryshchyshyn AP, Havryluk DY, Atamanyuk DV, Subtel'na IY, Khyluk DV. Thiazolidinone motif in anticancer drug discovery Experience of DH LNMU medicinal chemistry scientific group. 2011; 27(2): 107-17.

14. Baell JB, Nissink JWM. Seven Year Itch: Pan-Assay Interference Compounds (PAINS) in 2017-Utility and Limitations. ACS Chem Biol. 2018; 13(1): 36-44.

15. Mendgen T, Steuer C, Klein CD. Privileged Scaffolds or Promiscuous Binders: A Comparative Study on Rhodanines and Related Heterocycles in Medicinal Chemistry. J Med Chem. 2012; 55(2): 743-53.

16. Maddila S, Gorle S, Jonnalagadda SB. Drug screening of rhodanine derivatives for antibacterial activity. Expert Opin Drug Discov. 2020; 15(2): 203-29.

17. Jackson N, Czaplewski L, Piddock LJ V. Discovery and development of new antibacterial drugs: learning from experience? J Antimicrob Chemother. 2018; 73(6): 1452-9.

18. Sundaram K, Ravi S. Synthesis, antibacterial activity against MRSA, and in vitro cytotoxic activity against HeLa cell lines of novel 3 - $\alpha$-carboxy ethyl5-benzylidene rhodanine derivatives. Res Chem Intermed. 2015; 41(2): 1011-21.

19. Brvar M, Perdih A, Hodnik V, Renko M, Anderluh G, Jerala $R$, Solmajer $T$. In silico discovery and biophysical evaluation of novel 5-(2-hydroxybenzylidene) rhodanine inhibitors of DNA gyrase B. Bioorg Med Chem. 2012; 20(8): 2572-80.

20. Tejchman W, Korona-Glowniak I, Malm A, Zylewski M, Suder P. Antibacterial properties of 5-substituted derivatives of rhodanine-3-carboxyalkyl acids. Med Chem Res. 2017; 26(6): 1316-24.

21. Li W, Zheng C-J, Sun L-P, Song M-X, Wu Y, Li Y-J, Liu $Y$, Piao $H-R$. Novel arylhydrazone derivatives bearing a rhodanine moiety: synthesis and evaluation of their antibacterial activities. Arch Pharm Res. 2014; 37(7): 852-61.

22. Yapar $N$. Epidemiology and risk factors for invasive candidiasis. Ther Clin Risk Manag. 2014; 10: 95105. 
23. Wilson D, Dimondi V, Johnson $S$, Jones T, Drew $R$. Role of isavuconazole in the treatment of invasive fungal infections. Ther Clin Risk Manag. 2016; 12: 1197-206.

24. AbdelKhalek A, Ashby CR, Patel BA, Talele TT, Seleem MN. In Vitro Antibacterial Activity of Rhodanine Derivatives against Pathogenic Clinical Isolates. PLoS One. 2016; 11(10): e0164227.

25. Nagahara $M$, Ohishi Y, Yajima M, Nogimori $K$, Kurokawa S, Kajikawa N. Rhodanines useful as a therapeutic agent for diabetic complications. USPat. 4606860A. Appl. no.: 675,580 28.11.1984. Published 19.08.1986.

26. Wojtyra MN. Synthesis and biological activity of thiazolidine derivatives with pyridine moiety in molecules. Thesis for candidate's degree in pharmaceutical sciences in the speciality 15.00.02. Danylo Halytsky LNMU, Lviv 2017.

27. EUCAST. Antimicrobial susceptibility testing EUCAST disk diffusion method Version 80 January. Eur Soc Clin Microbiol Infect Deseases. 2020; (January): 1-21.

28. Magiorakos A-P, Srinivasan A, Carey RB, Carmeli Y, Falagas ME, Giske CG, Harbarth S, Hindler JF, Kahlmeter G, Olsson-Liljequist B, Paterson DL, Rice LB, Stelling J, Struelens MJ, Vatopoulos A, Weber JT, Monnet DL. Multidrug-resistant, extensively drug-resistant and pandrug-resistant bacteria: an international expert proposal for interim standard definitions for acquired resistance. Clin Microbiol Infect. 2012; 18(3): 268-81.

29. Lethu S, Bosc D, Mouray E, Grellier P, Dubois J. New protein farnesyltransferase inhibitors in the 3 -arylthiophene 2-carboxylic acid series: diversification of the aryl moiety by solid-phase synthesis. J Enzyme Inhib Med Chem. 2013; 28(1): 163-71.

30. Pérez-Cruz F, Serra S, Delogu G, Lapier $M$, Maya JD, Olea-Azar C, Santana L, Uriarte E. Antitrypanosomal and antioxidant properties of 4-hydroxycoumarins derivatives. Bioorganic Med Chem Lett. 2012; 22(17): 5569-73.

31. Körner H. Über einige Derivate der Dithiocarbamino-essigsäure. Berichte der Dtsch Chem Gesellschaft. 1908; 41(2): 1901-5.
32. Holota S, Kryshchyshyn A, Derkach H, Trufin Y, Demchuk I, Gzella A, Grellier P, Lesyk R. Synthesis of 5-enamine-4-thiazolidinone derivatives with trypanocidal and anticancer activity. Bioorg Chem. 2019; 86: 126-36.

33. Bolognesi ML, Cavalli A. Multitarget Drug Discovery and Polypharmacology. ChemMedChem. 2016; 11(12): 1190-2.

34. Bottegoni G, Favia AD, Recanatini M, Cavalli A. The role of fragment-based and computational methods in polypharmacology. Drug Discov Today. 2012; 17(1-2): 23-34.

35. Kryshchyshyn A. Fragment-based drug design (FBDD). J Org Pharm Chem. 2017; 15(1 (57)): $28-44$.

\section{5-Ен-роданін-3-карбонові кислоти як потенційні протимікробні та протипаразитарні агенти}

\section{А. П. Крищишин-Дилевич}

Мета. Розробка, синтез та дослідження антибактеріальної, протигрибкової та трипаноцидної активності ряду нових 2-тіоксо-4-тіазолідинон-3-карбонових кислот з різними ариліденовими замісниками у положенні С5. Методи. Органічний синтез, аналітичні та спектральні методи, фармакологічний скринінг, SAR аналіз. Результати. Ряд 5-(амінометилен)-4-оксо-2-тіоксотіазолідин-3-ілкарбонових кислот та їх аналогів ІІІаIII синтезовано у реакціях 5-(етоксиметилен)-4-оксо2-тиоксотіазолідин-3-ілкарбонових кислот Іа,, або етил 5- (етоксиметилен)-4-оксо-2-тіоксотіазолідин-3ілпропаноату IIc із різноманітними амінами та гідрокарбонатом амонію. Для п’яти синтезованих сполук IIIb, IIIf та IIIh-j досліджувалася інгібуюча активність щодо ряду Грам (+) та Грам (-) бактерій та чотирьох штамів дріжджів у дозі 1 мМ. Загалом, досліджувані сполуки є перспективними будівельними блоками для розробки протигрибкових засобів, оскільки всі вони пригнічували ріст клінічного штаму Candida albicans. Крім того, для піридинвмісних 3-[5-(амінометилен)роданін-3-іл]карбоксилати характеризувалися доброю трипаноцидною активністю та низькою цитотоксичністю щодо нормальних фібробластів. Висновки. Синтезовано ряд нових похідних 3-[5-(амінометилен)- 
4-оксо-2-тіоксотіазолідин-3-іл]карбонових кислот. Вивчення їх антибактеріальної та протигрибкової дії дозволило виявити сполуку-хіт етиловий естер 3-[5-[(4-(флюороаніліно)метилен]-4-оксо-2тіоксотіазолідин-3-іл]пропанової кислоти IIIf, що інгібував ріст клінічних штамів Staphylococcus lentus та Candida ssp. Загалом, більшість досліджуваних сполук виявляли добрі протигрибкові властивості.

К л ю ч о в і с л о в а: 2-тіоксо-4-тіазолідинон-3-карбонові кислоти, роданін, синтез, антитрипаносомна активність, антибактеріальна активність, протигрибкова активність, SAR.

\section{5-Ен-роданин-3-карбоновые кислоты как потенциальные противомикробные и противопаразитарные агенты}

\section{А. П. Крищишин-Дилевич}

Цель. Разработка, синтез и исследование антибактериальной, противогрибковой и трипаноцидной активности ряда новых 2-тиоксо-4-тиазолидинон-3-карбоновых кислот с различными арилиденовимы заместителями в положении С5. Методы. Органический синтез, аналитические и спектральные методы, фармакологический скрининг, SAR анализ. Результаты. Ряд 5-(аминометилен)-4-оксо-2-тиоксотиазолидин-3-илкарбонових кислот и их аналогов ІІІа-IIJ синтезированы в реакциях 5- (етоксиметилен)-4-оксо-2-тиоксотиазолидин-3-илкарбонових кислот ІІа,b или этил 5-(етоксиметилен)-4-оксо-2-тиоксотиазоли- дин-3-илпропаноата ІІс с различными аминами и гидрокарбонатом аммония. Для пяти синтезированных соединений IIIb, IIIf и IIIh-j исследовалась ингибирующая активность в отношении ряда Грам (+) и Грам (-) бактерий и четырех штаммов дрожжей в дозе 1 мМ. Исследуемые соединения являются перспективными строительными блоками для разработки противогрибковых средств, поскольку все они подавляли рост клинического штамма Candida albicans. Кроме того, пиридинсодержащие 3-[5-(аминометилен)-роданин-3-ил]карбоксилаты характеризовались хорошей трипаноцидной активностью и низкой цитотоксичностью к нормальным фибробластам. Выводы. Синтезирован ряд новых производных 3-[5-(аминометилен)-4-оксо-2-тиоксотиазолидин-3-ил]карбоновых кислот. Изучение их антибактериальной и противогрибковой активности позволило выявить соединение-хит этиловый эфир 3-[5-[(4-(флюороанилино)метилен]-4-оксо-2-тиоксотиазолидин-3-ил]пропановой кислоты IIIf, который ингибировал рост клинических штаммов Staphylococcus lentus и Candida ssp. В целом, большинство исследуемых соединений проявляли хорошие противогрибковые свойства.

Кл юч евы е с л ов а: 2 тиоксо-4-тиазолидинон-3-карбоновые кислоты, роданин, синтез, антитрипаносомная активность, антибактериальная активность, противогрибковая активность, SAR.

Received 20.03.2020 